\title{
Effects of water-column enrichment on the production dynamics of three seagrass species and their epiphytic algae
}

\author{
Donna J. Wear ${ }^{1, *}$, Michael J. Sullivan ${ }^{2}$, Allen D. Moore ${ }^{2}$, David F. Millie ${ }^{3}$ \\ ${ }^{1}$ Department of Biology, Augusta State University, 2500 Walton Way, Augusta, Georgia 30904-2200, USA \\ ${ }^{2}$ Department of Biological Sciences, PO Drawer GY, Mississippi State University, Mississippi State, Mississippi 39762, USA \\ ${ }^{3}$ US Department of Agriculture, Agricultural Research Service, Southern Regional Research Center, 1100 Robert E. Lee \\ Boulevard, New Orleans, Louisiana 70124, USA
}

\begin{abstract}
Monospecific beds of the seagrasses Halodule wrightii, Syringodium filiforme and Thalassia testudinum were enriched with a slow-release Osmocote ${ }^{\mathrm{TM}}$ (N-P-K) fertilizer from August 1993 through September 1994. Primary production rates (as ${ }^{14} \mathrm{C}$ uptake), biomass (dry weight), and chlorophyll a (chl a) (measured by HPLC) of epiphytes in enriched beds were significantly greater than those of epiphytes in control beds. Based on microscopic observations, the dominant epiphytic algae were diatoms and red and brown algae. Populations of the brown alga Myriotrichia subcorymbosa and the red alga Acrochaetium flexuosum increased greatly in enriched plots of all 3 seagrass species. Multiple linear regression supported observational data in that pigment signatures selected for the dominant epiphytes (fucoxanthin, zeaxanthin, and violaxanthin) explained $97 \%$ of the variation in chl a. A. strong correlation between measured and predicted chl $a(r=0.98)$ suggested that chl $a$ is an excellent indicator of epiphytic biomass in this system. Production rates of blades increased in enriched plots relative to controls but biomass of blades was unaffected. The strong response of epiphytes to enrichment suggests that cultural eutrophication could pose a threat to seagrass beds of Big Lagoon, Perdido Key, Florida, USA. Negative effects could be manifested as a reduction in the coverage of shallow-water sediments by seagrass beds and/or the elimination of 1 or 2 species, possibly converting Big Lagoon into a seagrass monoculture.
\end{abstract}

KEY WORDS: Eutrophication - Primary production - Epiphytic algae · Seagrasses · Pigments

\section{INTRODUCTION}

The worldwide extent of seagrass vegetation has declined considerably during the last several decades (Orth \& Moore 1983, Walker \& McComb 1992). Increased concentrations of water-column nutrients caused by cultural eutrophication are considered to be the primary factor leading to seagrass demise (Cambridge \& McComb 1984, Duarte 1991, Sand-Jensen \& Borum 1991). Nutrient enrichment stimulates the growth of phytoplankton and epiphytic algae on seagrass leaves and thus reduces the spectral quality

•E-mail: dwear@aug.edu and/or amount of light available to the photosynthetic tissues of the seagrasses (Orth \& Moore 1983, Silberstein et al. 1986). Light attenuation is, therefore, a secondary effect of nutrient enrichment, and these factors synergistically affect the health and vigor of seagrasses (Sand-Jensen \& Borum 1991).

Because the effects of water-column enrichment on seagrasses are thought to be mediated through the epiphytic algae, simultaneous measurement of the responses of both autotrophic components (the seagrass-epiphyte complex) to enrichment is necessary. We used ${ }^{14} \mathrm{C}$ uptake rates and measurements of biomass to assess the responses of seagrass blades and their epiphytes to water-column enrichment. We hypothesized that water-column enrichment would 
increase production rates of epiphytic algae and decrease production rates of seagrass blades. We also examined the response of the dominant epiphytic algal groups to mutrient enrichment

\section{MATERIALS AND METHODS}

Study site. All field work was conducted within seagrass beds at Big Lagoon, Perdido Key, Florida, USA (Fig. 1). Perdido Bay is a shallow, brackish inlet which is influenced by seasonal shifts in prevailing winds and freshwater inflow from the adjacent mainland. This area is unique because monospecific beds of 3 seagrass species Halodule wrightii Ascherson, Syringodium filiforme Kützing, and Thalassia testudinum Banks ex König are present. These seagrasses are abundant and widely distributed in the Gulf of Mexico, along the east coast of Florida, and in the West Indies.

For each of the 3 seagrass species, 4 experimental plots were selected. Two of the 4 plots were designated for water-column enrichment and 2 served as controls. All plots were located at least $20 \mathrm{~m}$ apart. Control and enriched plots of Halodule wrightii were approximately $82 \mathrm{~cm}$ deep. Control and enriched plots of Syringodium filiforme and Thalassia testudinum were approximately $125 \mathrm{~cm}$ deep.

Nutrient enrichment. Fifty-four sections of $5 \mathrm{~cm}$ diameter PVC pipe were cut to $20.5 \mathrm{~cm}$ lengths. Six equally spaced, longitudinal rows of $6,6.4 \mathrm{~mm}$ holes were drilled in each section, which was termed a tube. A plastic cap was glued onto 1 end of each tube and a screw cap was fitted to the other end. A nylon stocking placed in each tube was filled with $454 \mathrm{~g}$ of a slowrelease ( 3 to $4 \mathrm{mo}$ ), temperature-sensitive Osmocote ${ }^{T M}$ fertilizer. This fertilizer contained $19 \% \mathrm{~N}$ (as ammonium nitrate), $6 \% \mathrm{P}$ (as anhydrous phosphoric acid),

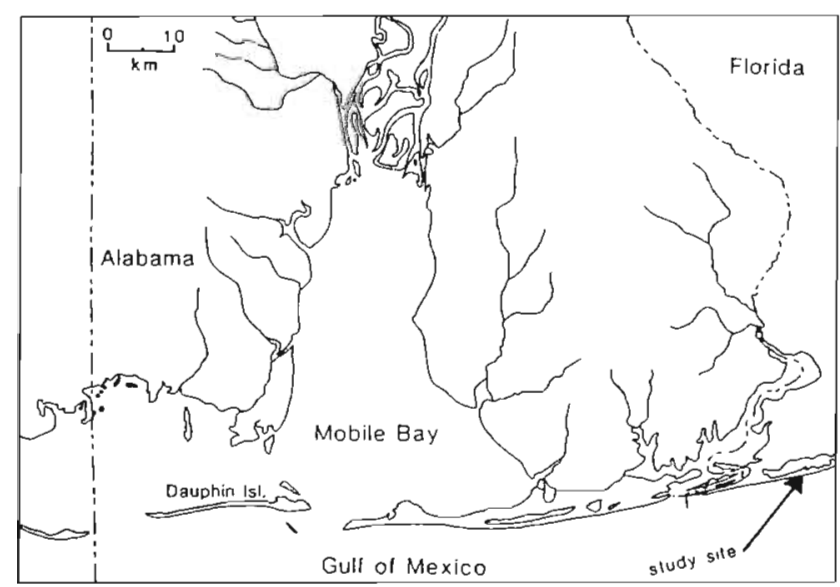

Fig. 1. Big Lagoon, Perdido Key, Florida, USA, showing location of study area and $12 \% \mathrm{~K}$ (as anhydrous potassium hydroxide) by weight. Laboratory experiments at the Dauphin Island Sea Lab, Dauphin Island, Alabama, demonstrated that this fertilizer releases nutrients to the water column at a constant rate (J. Pennock pers. comm.).

Nine dispensing tubes were anchored vertically in each of the 6 plots designated for enrichment $(2$ plots for each seagrass species). Eight tubes were spaced equidistantly in a circle (1.5 $\mathrm{m}$ diameter) in the middle of the plot and 1 tube was placed at the center of the circle. During summer, early fall, and late spring, nutrient tubes were cleaned and replaced approximately every 3 wk to ensure a constant release of fertilizer. Each time nutrient tubes were changed, 10 tubes were selected at random and the fertilizer from these tubes was dried to a constant weight $\left(60^{\circ} \mathrm{C}\right)$ and reweighed to provide an estimate of daily fertilizer release.

Nutrient enrichment began in August 1993 and continued through September 1994. Sampling was conducted approximately every 2 mo from October 1993 to September 1994 for a total of 6 sampling dates.

Sampling strategy. On each sampling date, treatment effects were quantified by measuring in situ primary production rates and biomass of both seagrasses and epiphytes in each of the 12 experimental plots. In each of the 6 enriched plots, samples were obtained from within the circle of tubes. Samples were also obtained from each plot for determination of epiphytic algal community structure. Water temperature, salinity and photosynthetically active radiation (PAR) (400 to $700 \mathrm{~nm}$ ) were measured during primary production incubations. PAR measurements were obtained in air and at the sediment surface in seagrass beds using a LI-COR Quantum/Radiometer/Photometer (cosinecorrected) Model No. LI-185B. PAR was measured at the midpoint of the $2 \mathrm{~h}$ incubation period and measurements were collected nearly simultaneously.

On 3 and 27 June 1994, 2 nutrient tubes without fertilizer were placed in the field at distances of 1 and $2 \mathrm{~m}$ from a tube containing fertilizer. These experiments were conducted to provide information regarding the effect of current on fertilizer dispersion after nutrients were released into the water column (i.e. fertilizer drift). If fertilizer release was relatively unaffected by water current, a gradient with regard to the colonization of algae on tubes was anticipated, with the least algae occurring on the tube that was $2 \mathrm{~m}$ away. Tubes remained in the field for about 3 wk and were then removed and photographed.

Primary production measurements. Primary production rates were determined separately for seagrasses and their epiphytes by ${ }^{14} \mathrm{C}$ uptake measurements. Our technique was a modification of that of Penhale (1977). Seagrass blades with attached epiphytes were placed in incubation chambers (glass, 
screw-cap test tubes). Three incubation chambers were used in each of the 12 experimental plots. Each chamber was filled with unfiltered seawater, and the contents of a $1 \mathrm{ml}, 5 \mu \mathrm{Ci}$ ampule of sodium bicarbonate $\left(\mathrm{NaH}^{14} \mathrm{CO}_{3}\right)$ were injected with a 22 gauge needle and syringe. An 18 gauge needle and syringe were used to inject an aliquot of dichlorophenyl dimethyl urea (DCMU) into 1 incubation chamber per plot so that the final concentration of DCMU per chamber was $10^{-5} \mathrm{M}$. The uptake rate determined for the chamber containing DCMU was used to correct for inactive uptake of ${ }^{14} \mathrm{C}$ (Legendre et al. 1983). Similarly, determination of the primary production rate of phytoplankton (incubated in BOD bottles) was used to correct for ${ }^{14} \mathrm{C}$ uptake by phytoplankton in each incubation chamber. Samples were incubated in situ for $2 \mathrm{~h}$ before incubation was stopped with the addition of $4 \%$ buffered formalin.

In the laboratory, epiphytes were scraped from seagrass blades with a silicon rubber stopper (Burkholder \& Wetzel 1990) and collected on a $0.45 \mu \mathrm{m}$ cellulosic membrane filter. Surface adsorbed label was removed from epiphytes with washes of $2 \% \mathrm{HCl}$. The surface area of seagrass blades was measured on a LI-COR (Model LI-3000) portable surface area meter. Blade surface area was determined so that primary production rates for both seagrass blades and epiphytes could be expressed on a $\mathrm{cm}^{2}$ basis. Samples were burned in a biological material oxidizer (R. J. Harvey, Model OX500); a liquid scintillation counter (Beckman LS 3801) determined ${ }^{14} \mathrm{C}$ disintegrations $\mathrm{min}^{-1}$ (dpm).

The method of Strickland \& Parsons (1977) was used to calculate field $\mathrm{pH}$ and the total amount of ${ }^{12} \mathrm{C}$ available for uptake in incubation chambers. ${ }^{14} \mathrm{C}$ dpm were converted to carbon uptake rates using the formula

$$
\{[(L-D) / R] \times A \times C\} / P \times T
$$

where $L=\mathrm{dpm}$ of sample, $D=\mathrm{dpm}$ of sample containing DCMU, $R=$ efficiency of sample oxidizer, $A=$ total ${ }^{12} \mathrm{C}$ available for uptake ( $\mathrm{mg} \mathrm{ml}^{-1}$ ) multiplied by the volume of the incubation chamber ( $\mathrm{ml}$ ), $C=1.064$ (correction term for difference in ${ }^{12} \mathrm{C}$ and ${ }^{14} \mathrm{C}$ isotopic

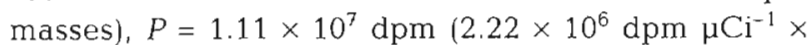
$5 \mu \mathrm{Ci}{ }^{14} \mathrm{C}$ sample $\left.{ }^{-1}\right)$, and $T=$ incubation time in $\mathrm{h}$. The result was divided by the total surface area of blades in each sample to standardize uptake rates for blades and epiphytes.

Biomass determinations. Aboveground live biomass in control and nutrient-enriched seagrass beds was estimated by a method similar to that of Morgan \& Kitting (1984). Two $10 \times 10 \mathrm{~cm}$ quadrats were selected in each bed. All blades in each quadrat were clipped at the sediment surface and placed in a plastic bag. Several blades were subsampled ( 8 to 15 ) from each quadrat and these were placed in a separate plastic bag. Subsampling of blades was done immediately after blades were clipped, because epiphytes may fall from blades after being removed from the water. A small amount of water was added to the bags containing the samples before they were placed on ice for transport.

In the laboratory, the total number of blades per quadrat (including the number which was subsampled) was counted. Epiphytes were scraped from the subsamples with a silicon-rubber stopper (Burkholder \& Wetzel 1990). Blades and epiphytes were placed in separate aluminum weighing dishes and were dried at $60^{\circ} \mathrm{C}$ to a constant weight. The total number of blades in each quadrat was divided by the number of blades in each subsample and this number was multiplied by the dry weight of epiphytes and blades to determine the contribution of each to total dry weight. Measurements of biomass were not conducted during January.

Epiphytic community structure and pigment profiles. On each sampling date, approximately 20 seagrass blades with attached epiphytes were clipped from each of the 12 experimental plots. Half of the total number of blades was placed in each of 2 plastic bags. A small amount of seawater was added to each bag and samples were stored immediately on ice. In the laboratory, 1 bag from each plot was used for the identification of epiphytic algae, and the other was used for pigment analysis. Non-diatom epiphytic algae were identified to genus or species when possible. A species list of epiphytes by phylogenetic group (division) was recorded for each experimental plot on each sampling date. The dominance of macroalgae was determined by the number of times they appeared in a number of randomly selected fields. A minimum of 30 fields was counted per plot per date.

Samples used for pigment analysis were processed in a darkened room to minimize pigment degradation. Epiphytes were scraped from blades and filtered onto $0.7 \mu \mathrm{m}$ glass microfiber filters (Whatman GF/F). Filters were folded in half, dried with paper toweling, and frozen at $-80^{\circ} \mathrm{C}$ (Revco Model ULT1786). The surface area of cleaned blades was determined as described above.

High-performance liquid chromatography (HPLC) was used to identify and quantify phylogenetic groups of algae (at the division or class levels) based on the presence and amounts of pigments which are unique to, or 'diagnostic' of, each algal group (Millie et al. 1993). Concentrations of chlorophyll a (chl a), fucoxanthin, violaxanthin, lutein, and zeaxanthin were determined because they are characteristic of the algal groups observed in live material. Chl a was used to estimate the abundance of all algal taxa. Fucoxanthin is characteristic of brown algae (Phaeophyta) and diatoms (Bacillariophyta), whereas violaxanthin is 
found in brown algae but occurs only in low concentrations or is absent in diatoms (Rowan 1989). The concentration of lutein was used to estimate the abundance of green algae (Chlorophyta). The concentration of zeaxanthin was used as an indicator of the abundance of red algae (Rhodophyta). Although Cyanobacteria also contain zeaxanthin, microscopic examination of live material indicated that few cyanobacteria were present as epiphytes. Measurements of pigment concentrations were not conducted in October.

Data analysis. Statistical Analysis System (SAS 1988) for Windows was used for all data analyses. A modified split-plot design which accounted for sampling over time was used for the analysis of variance of primary production and biomass data. The least significant difference (LSD) test was used for separation of means. Blade production and epiphytic production were used as response variables in the andlysis of primary production data. The dry weights of blades and epiphytes were used as response variables in the analysis of biomass data. Pigment data were also subjected to a modified split-plot design which accounted for sampling over time. The pigments chl $a$, fucoxanthin, violaxanthin, lutein, and zeaxanthin were used as response variables to distinguish among the abundances of epiphytic algal groups. Because the variables seagrass species and time were not significant sources of variation, the pigment data were reanalyzed using a completely randomized design and the variables were pooled with the error term to increase error degrees of freedom. Multiple linear regression was used to determine how well the analyzed pigments predicted chl a.

\section{RESULTS}

\section{Environmental data}

Water temperature ranged from $29^{\circ} \mathrm{C}$ in September to $7^{\circ} \mathrm{C}$ in January (Table 1). The lowest salinity was recorded in August (13 ppt) and the highest in October (27 ppt). Low salinity was a result of an increase in the amount of regional rainfall immediately preceding the sampling date. PAR was consistently lower in beds of Syringodium filiforme and Thalassia testudinum than in beds of Halodule wrightii. $H$. wrightil occurs at shallower depths than the other 2 species in Big Lagoon and therefore receives a greater amount of PAR (Table 1).

\section{Fertilizer release}

Based on dry weight measurements of the remaining fertilizer in 90 randomly selected nutrient tubes, the

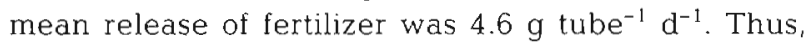

Table 1. Environmental data for seagrass beds on each sampling date from October 1993 to September 1994. ppt: parts per thousand; PAR: photosynthetically active radiation; $\mu E$ : $\mu \mathrm{E} \mathrm{m}^{-2} \mathrm{~s}^{-1}$; H: Halodule wrightii $\mathrm{i}_{\mathrm{S}} \mathrm{S}$ : Syringodium filiforme; $\mathrm{T}$ : Thalassia testudinum; PAR values are mean values measured during the incubations. Ambient PAR is that above the airwater interface. H PAR and S and T PAR represent the PAR actually reaching the sediment surface beneath the seagrassepiphyte complex. PAR measurments were made at the midpoint of the $2 \mathrm{~h}$ incubation period

\begin{tabular}{|lrrrrrr|} 
& 28 & 10 & 1 & 26 & 3 & 2 \\
& Oct & Jan & Apr & Jun & Aug & Sep \\
\cline { 1 - 5 } Water temp. $\left({ }^{\circ} \mathrm{C}\right)$ & 21 & 7 & 17 & 28 & 27 & 29 \\
Salinity $(\mathrm{ppt})$ & 27 & 25 & 20 & 19 & 13 & 18 \\
Ambient PAR $(\mu \mathrm{HE})$ & 1650 & 350 & 1600 & 1700 & 1500 & 1800 \\
H PAR $(\mu \mathrm{HE})$ & 650 & 300 & 1000 & 1000 & 350 & 700 \\
S and T PAR $(\mu \mathrm{E})$ & 425 & 175 & 500 & 275 & 100 & 200 \\
& & & & & & \\
\hline
\end{tabular}
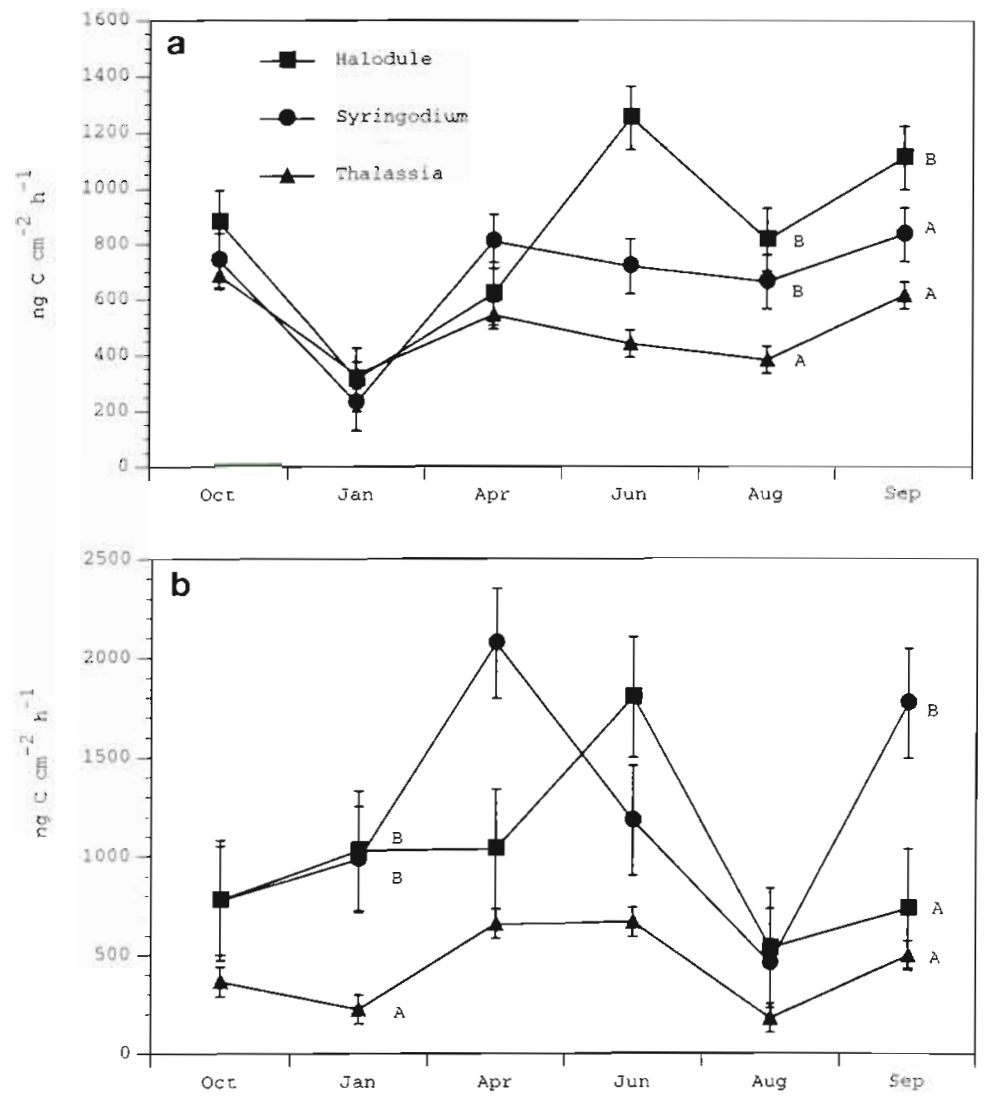

Fig. 2. Mean hourly primary production rates and their standard errors for (a) seagrass blades and (b) epiphytes from October 1993 to September 1994. Means with the same letter are not significantly different $(n=8)$ 
approximately $41.4 \mathrm{~g} \mathrm{~d}^{-1}$ of fertilizer was released in each of the 6 enriched plots yielding a total of $248.4 \mathrm{~g}$ $\mathrm{d}^{-1}$ of fertilizer released into the system.

The 2 experiments designed to test for the effects of current on fertilizer dispersion showed that there was a gradient with regard to colonization of tubes by algae. The greatest biomass of algae (which included mainly the green alga Enteromorpha and diatoms) occurred on the tube containing fertilizer and the least biomass (which consisted mostly of diatoms) occurred on the tube that was placed $2 \mathrm{~m}$ away. These data supported our observation that flow rates are low in Big Lagoon. Furthermore, because of the distance between plots $(\geq 20 \mathrm{~m})$, these experiments provided evidence that the possibility of fertilizer drifting into and contaminating control plots was extremely remote.

\section{Primary production}

The combined analysis of variance showed that a 2 -way interaction term (seagrass species $x$ time) and the main effect of fertilizer were significant for both response variables (seagrass blade productivity and epiphytic productivity) (Table 2). In August ${ }^{14} \mathrm{C}$ uptake by blades of Thalassia testudinum was significantly less than uptake rates of blades of Syringodium filiforme and Halodule wrightii, whereas in September ${ }^{14} \mathrm{C}$ uptake by blades of $H$. wrightii was significantly greater than that by blades of the other 2 seagrasses (Fig. 2a). In January, ${ }^{14} \mathrm{C}$ uptake by epiphytes of $T$. testudinum was significantly less than uptake rates for epiphytes of $H$. wrightii and $S$. filiforme (Fig. 2b), whereas in September ${ }^{14} \mathrm{C}$ uptake by epiphytes of $S$. filiforme was greater than that by epiphytes of the other 2 seagrasses (Fig. 2 b).

Production rates of seagrass blades in enriched plots were $1.4 \times$ greater than rates of blades in control plots (Fig. 3a, Appendix 1). Production rates of epiphytic algae in enriched plots were $2.0 \times$ greater than those measured for control plots (Fig. 3b, Appendix 1). Furthermore, production rates of epiphytic algae in enriched plots were greater than corresponding rates of seagrass blades (Fig. 3a,b; note difference in scale, Appendix 1). However, production rates of blades and epiphytes in control plots were similar (Fig. 3a,b, Appendix 1).

The percent contribution of epiphytes to total primary production (seagrass blades + epiphytes) in enriched plots of Halodule wrightii $(60 \%)$ was greater than that in control plots ( $44 \%$ ) (Fig. 4 a). The relative contribution of epiphytes was almost equal in enriched and control plots of Syringodium filiforme (66 and $62 \%$, respectively) and Thalassia testudinum (48 and $50 \%$, respectively)(Fig. 4 a).

\section{Biomass measurements}

The combined analysis of variance showed that the main effects of seagrass species and time were significant for biomass of seagrass blades (Table 2). As expected, the mean dry weight of blades of Halodule

Table 2. Summary statistics of ANOVA for ${ }^{14} \mathrm{C}$ uptake rates and biomass of seagrass blades and epiphytes from October 1993 to September 1994 ("significance of $F$ value; $\alpha=0.05$ )

\begin{tabular}{|c|c|c|c|}
\hline Source & df & $F$ value & $p>F$ \\
\hline \multicolumn{4}{|l|}{${ }^{14} \mathrm{C}$ uptake rates } \\
\hline \multicolumn{4}{|c|}{ Response variable: blades } \\
\hline Fertilizer & 1 & 22.07 & $0.0182^{\circ}$ \\
\hline Time $\times$ species & 10 & 3.52 & $0.0036^{\circ}$ \\
\hline \multicolumn{4}{|c|}{ Response variable: epiphytes } \\
\hline Fertilizer & 1 & 24.21 & $0.0161^{\circ}$ \\
\hline Time $\times$ species & 10 & 2.24 & $0.0430^{\circ}$ \\
\hline \multicolumn{4}{|c|}{ Biomass } \\
\hline \multicolumn{4}{|c|}{ Response variable: blades } \\
\hline Seaqrass species & 2 & 17.66 & $0.0219^{\circ}$ \\
\hline Time & 4 & 4.53 & $0.0072^{\circ}$ \\
\hline \multicolumn{4}{|c|}{ Response variable: epiphytes } \\
\hline Fertilizer & 1 & 30.58 & $0.0117^{\circ}$ \\
\hline Time $\times$ species & 8 & 3.62 & $0.0067^{\circ}$ \\
\hline
\end{tabular}
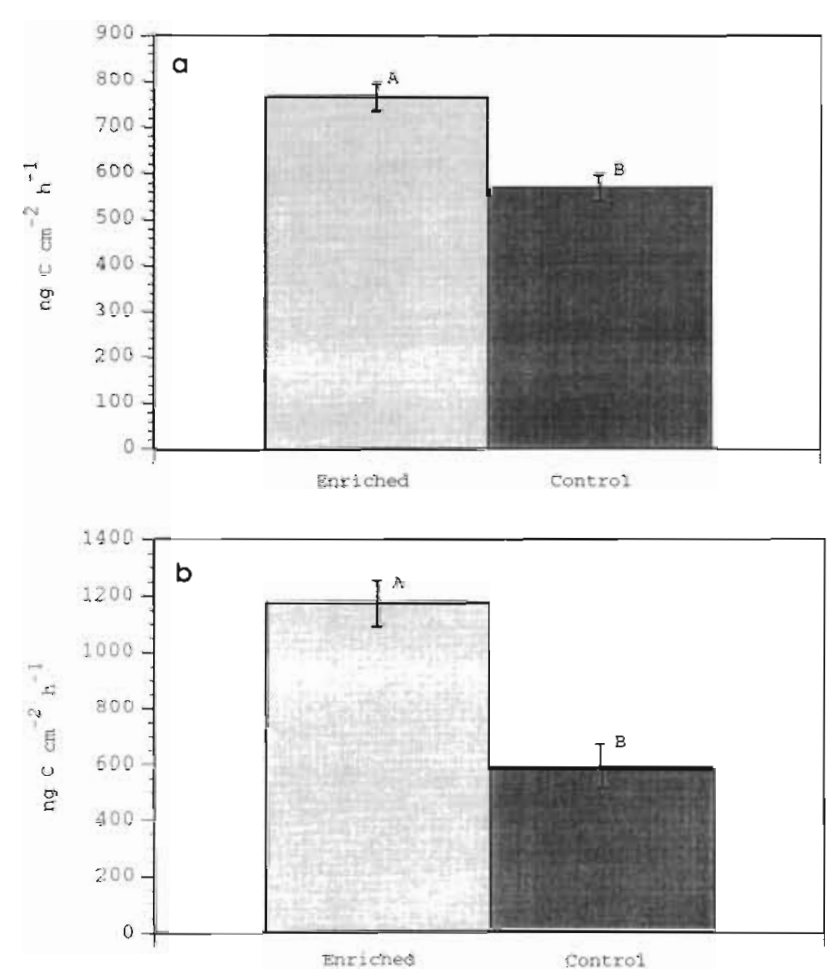

Fig. 3. Mean hourly primary production rates and their standard errors for (a) seagrass blades and (b) epiphytes in control and enriched plots from October 1993 to September 1994. Means with the same letter are not significantly different $(n=72)$ 

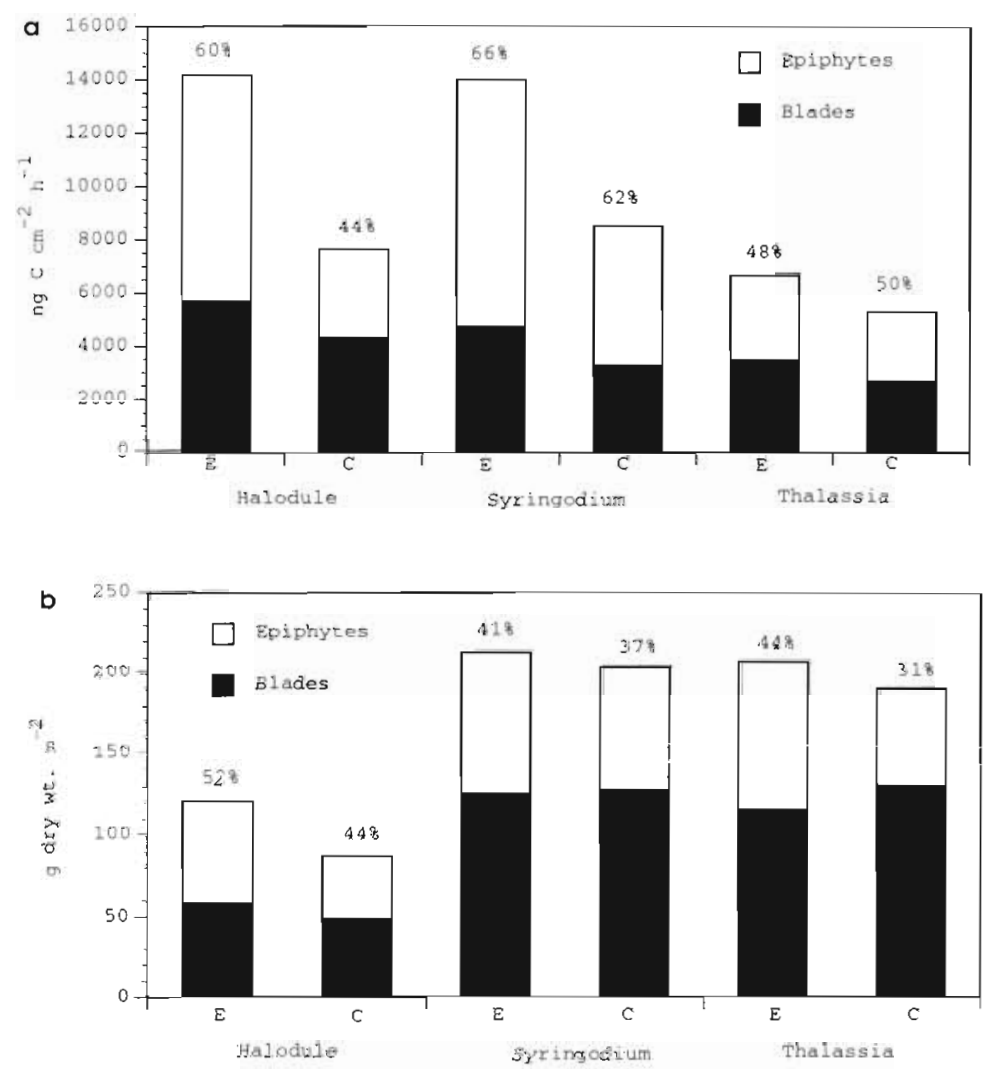

Fig. 4. Relative contributions of seagrass blades and epiphytes to (a) total primary production $(n=24)$ and (b) total biomass $(n=20)$ from October 1993 to September 1994; E: enriched; C: control; value above bar: \% contribution of epiphytes
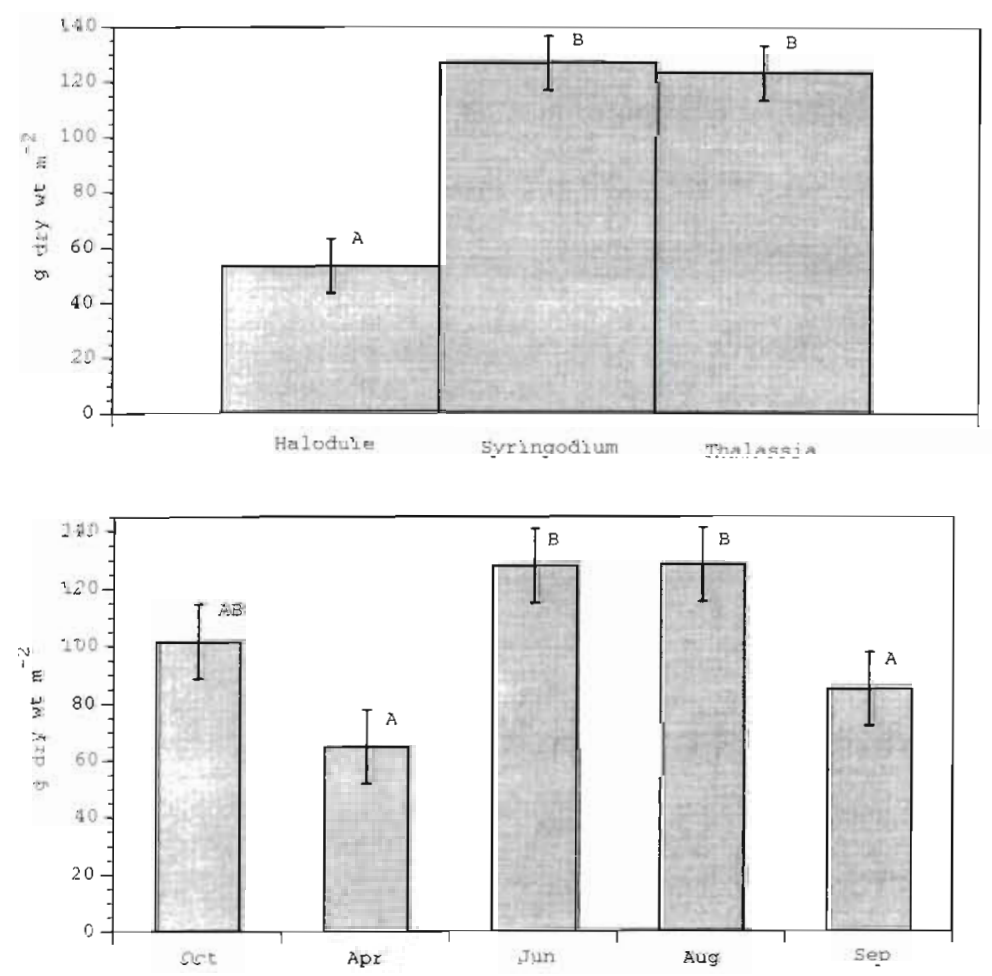

wrightii was less than that of blades of Syringodium fillorme and Thalassia testudinum (Fig. 5, Appendix 2), The mean biomass of blades of the 3 seagrass species combined was least in April and September and greatest in June and August (Fig. 6). Enrichment had no effect on biomass of seagrass blades.

Analysis of variance showed that a 2-way interaction term (seagrass species $\times$ time) and the main effect of fertilizer were significant for biomass of epiphytes (Table 2). The dry weight of epiphytes of Halodule wrightii was significantly less than that of epiphytes of Thalassia testudinum in September (Fig. 7). Mean biomass of epiphytes among the 3 species of seagrasses on all other sampling dates did not differ significantly (Fig. 7). In contrast, epiphytes in enriched plots had a $1.4 \times$ greater biomass than epiphytes in control plots (Fig. 8, Appendix 2).

The percent contribution of epiphytes to total biomass (seagrass blades + epiphytes) was greater in enriched plots than in control plots for all 3 seagrass species (Fig. 4b). Percent contribution of epiphytes (31 to $44 \%$ ) to total biomass was less than that of blades for all species and all treatments except for enriched plots of Halodule

Fig. 5. Mean biomass values and their standard errors for blades of each seagrass species from October 1993 to September 1994. Means with the same letter are not significantly different $(n=40)$

Fig. 6. Mean biomass values and their standard errors for seagrass blades of the 3 seagrass species combined from October 1993 to September 1994. Means with the same letter on a sampling date are not significantly different $(n=24)$ 


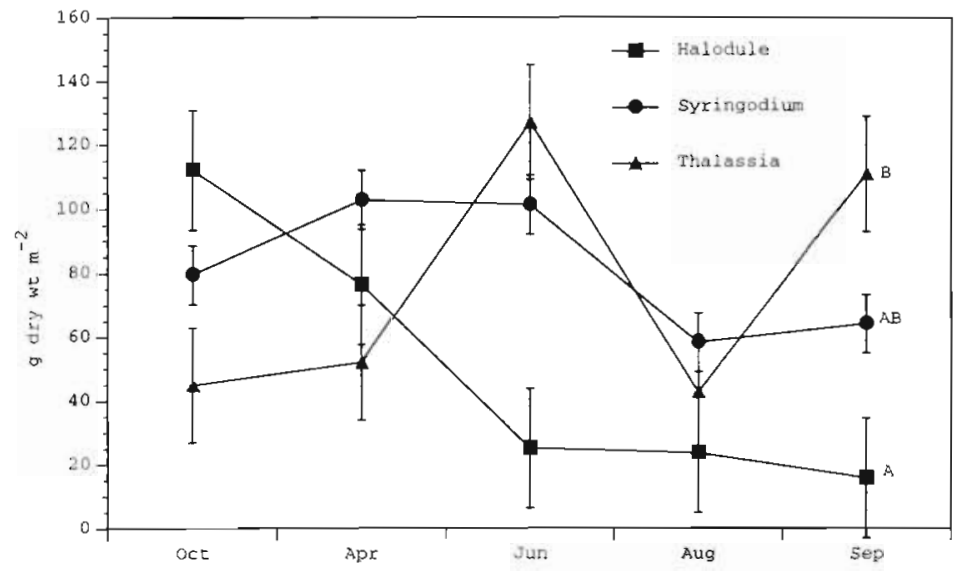

Fig. 7. Mean biomass values and their standard errors for epiphytes of each seagrass species from October 1993 to September 1994. Means with the same letter on a sampling date are not significantly different $(n=8)$

wrightii, where epiphytes contributed $52 \%$ to total biomass (Fig. 4b). Furthermore, the potential trophic importance of epiphytes to the system is suggested more by the relative contributions of epiphytes to primary production than to biomass (Fig. 4a,b).

\section{Epiphytic algal community structure}

Microscopic examination of epiphytes showed that diatoms (Bacillariophyta) were the most abundant algal group in both control and enriched plots. Species richness of macroalgae in Big Lagoon was highest among the red algae (Rhodophyta) (Table 3 ). The abundance of macroalgae was much lower in control than in enriched plots (Table 4). Enriched plots of Halodule wrightii had a greater species richness of epiphytic macroalgae than enriched plots of Syringodium

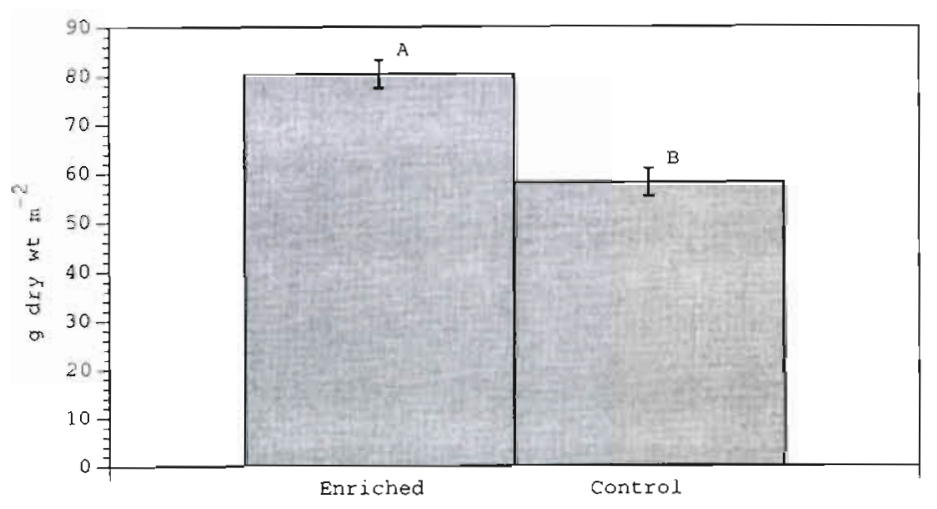

Fig. 8. Mean biomass values and their standard errors for epiphytes in control and enriched plots from October 1993 to September 1994. Means with the same letter are not significantly different $(n=60)$ filiforme and Thalassia testudinum (Table 4). Populations of the brown alga Myriotrichia subcorymbosa (Holden) Blomquist and the red alga Acrochaetium flexuosum Vickers increased greatly in enriched plots of all seagrass species.

Analysis of variance of HPLC data showed that there was a significant difference in epiphytic pigment concentrations between control and enriched plots for chl a, fucoxanthin (Appendix 3), violaxanthin, and zeaxanthin. No significant difference in the concentration of the pigment lutein was found between control and enriched plots (Tables 5 \& 6). Concentrations of chl $a$, fucoxanthin, and zeaxanthin were $3 \times$ greater and that of violaxanthin was $6 \times$ greater in enriched plots than in control plots (Table 6).

Multiple linear regression [using selections for Mallow's C(p) statistic, adjusted R-square, and mean square error] showed that the best model for predicting chl a was a 3 variable model which included concentrations of the pigments fucoxanthin (Fuco), violaxanthin (Viola), and zeaxanthin (Zea). This model

Table 3. Macroalgae identified as epiphytes of Halodule wrightii, Syringodium filiforme, and Thalassia testudinum in Big Lagoon, Perdido Key, Florida, USA. (October 1993 to September 1994)

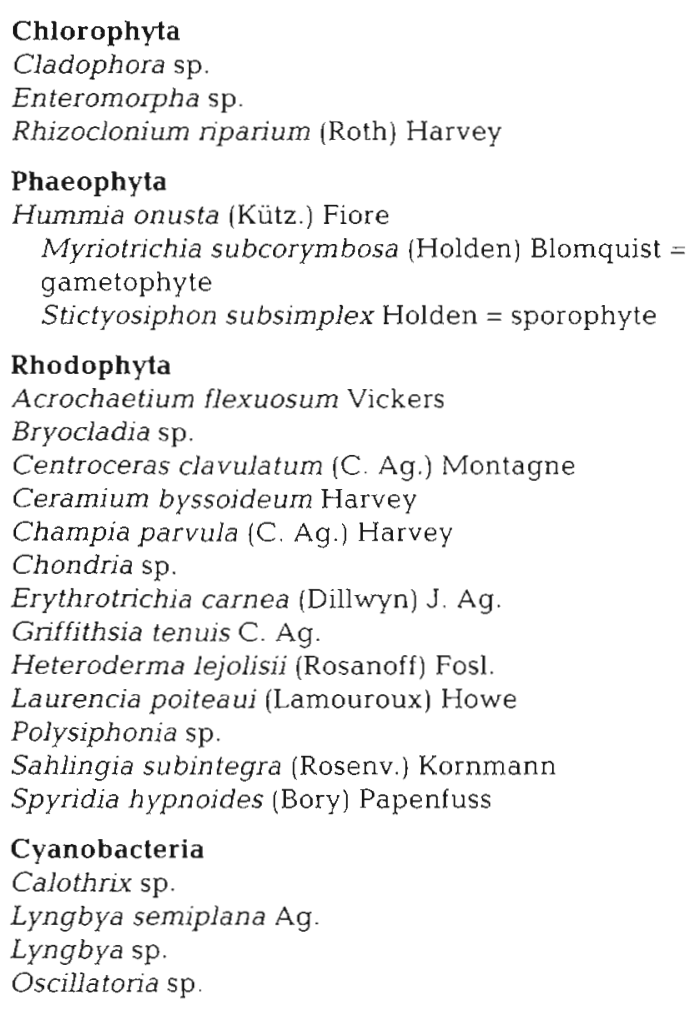


Table 4. Dominant epiphytic macroalgae in control and enriched plots of Halodule wrightii, Syringodium filiforme, and Thalassia testudinum from October 1993 to September 1994. Macroalgae are listed in order of decreasing abundance for each date and seagrass species; absence of names indicates low abundance of macroalgae. Refer to Table 3 for a complete list of scientific names. H: Halodule wrightii; S: Syringodium filiforme; T. Thalassia testudinum

\begin{tabular}{|c|c|c|c|c|c|c|}
\hline & October & January & April & June & August & September \\
\hline $\begin{array}{l}\text { Control } \\
\mathrm{H}\end{array}$ & Lyagbya & & & & & \\
\hline S & & $\begin{array}{c}\text { Champia } \\
\text { Heteroderma }\end{array}$ & & & & \\
\hline $\mathrm{T}$ & Heteroderma & & & & Polysiphonia & \\
\hline $\begin{array}{l}\text { Enriched } \\
\mathrm{H}\end{array}$ & $\begin{array}{l}\text { Erythrotrichia } \\
\text { Rhizoclonium }\end{array}$ & $\begin{array}{c}\text { Erythrotrichia } \\
\text { Myriotrichia }\end{array}$ & $\begin{array}{l}\text { Myriotrichia } \\
\text { Acrochaetium } \\
\text { Erythrotrichia } \\
\text { Stictyosiphon }\end{array}$ & $\begin{array}{l}\text { Heteroderma } \\
\text { Acrochaetium }\end{array}$ & Acrochaetium & Acrochaetium \\
\hline S & Lyngbya & $\begin{array}{l}\text { Myriotrichia } \\
\text { Acrochaetium }\end{array}$ & $\begin{array}{l}\text { Myriotrichia } \\
\text { Acrochaetium }\end{array}$ & & & \\
\hline$T$ & $\begin{array}{c}\text { Ileteroderma } \\
\text { Lyngbya }\end{array}$ & & Myriotrichia & $\begin{array}{l}\text { Myriotrichia } \\
\text { Acrochaetium }\end{array}$ & $\begin{array}{c}\text { Acrochaetium } \\
\text { Lyngbya }\end{array}$ & Lyngbya \\
\hline
\end{tabular}

may be expressed as Chl $a=-37.64+1.59$ Fuco +10.23 Viola + 16.84Zea. Lutein did not contribute significantly to the prediction of chl a; this finding was consistent with the observation of very few green algae (Tables 3,4 ). Collectively, the concentrations of fucoxanthin, violaxanthin, and zeaxanthin explained $97 \%$ $\left(\mathrm{R}^{2}=0.9691, \mathrm{n}=59\right)$ of the variation in chl a concentration (Fig. 9). The best single variable model contained the pigment fucoxanthin and explained $88 \%\left(\mathrm{R}^{2}=\right.$ 0.88 ) of the variation in chl $a$. This relationship is consistent with the great abundance of diatoms observed in live material (Appendix 3).

Table 5. Summary statistics of ANOVA for HPLC analysis of epiphytic chl a, fucoxanthin, violaxanthin, lutein, and zeaxanthin from January 1994 to September 1994 ('significance of $F$ value; $\alpha=0.05$ )

\begin{tabular}{|c|c|c|c|}
\hline Source & $d f$ & $F$ value & $\mathrm{p}>F$ \\
\hline \multicolumn{4}{|l|}{ Chl a } \\
\hline Fertilizer & 1 & 13.81 & $0.0005^{\circ}$ \\
\hline Error & 57 & & \\
\hline \multicolumn{4}{|c|}{ Fucoxanthin } \\
\hline Fertilizer & 1 & 16.00 & $0.0002^{\circ}$ \\
\hline Error & 57 & & \\
\hline \multicolumn{4}{|c|}{ Violaxanthin } \\
\hline Fertilizer & 1 & 8.08 & $0.0062^{\circ}$ \\
\hline Error & 57 & & \\
\hline \multicolumn{4}{|l|}{ Lutein } \\
\hline Fertilizer & 1 & 1.92 & 0.1714 \\
\hline Error & 57 & & \\
\hline \multicolumn{4}{|c|}{ Zeaxanthin } \\
\hline Fertilizer & 1 & 11.45 & $0.0013^{\circ}$ \\
\hline Error & 57 & & \\
\hline
\end{tabular}

Because violaxanthin has been reported in low concentrations in some species of diatoms (Rowan 1989), it was necessary to verify that this pigment was a valid indicator of the abundance of brown macroalgae. Brown algae were observed in high concentration in enriched plots, but their abundance was low in control plots (Table 4). If brown algae were the primary contributors of violaxanthin, then the correlation between this pigment and fucoxanthin should be lower in control than enriched plots because fucoxanthin is dominant in both diatoms and brown algae. Correlation analysis showed that the relationship between fucoxanthin and violaxanthin was significant in enriched plots $(r=0.67)$ but not significant in control plots $(r=$ 0.30 ). Furthermore, multicollinearity diagnostics (variance inflation factor, tolerance, and eigenvalues) showed that violaxanthin contributed unique information to the linear regression model for predicting $\mathrm{chl}$ a concentration.

Table 6. Mean pigment concentrations of epiphytic algae in control $(\mathrm{n}=30)$ and enriched plots $(\mathrm{n}=29)$ from January to September 1994 (SE: standard error; 'significant difference between control and enriched plots; $\alpha=0.05$ )

\begin{tabular}{|c|c|c|}
\hline $\begin{array}{l}\text { Pigment } \\
\left(\mathrm{ng} \mathrm{cm}^{-2}\right)\end{array}$ & $\begin{array}{c}\text { Control } \\
( \pm \mathrm{SE})\end{array}$ & $\begin{array}{c}\text { Enriched } \\
\quad( \pm S E)\end{array}$ \\
\hline Chlorophyll a & $492.9(194.1)$ & $1521.9(197.4)$ \\
\hline Fucoxanthin & $230.7(71.7)$ & $640.0(73.0)$ \\
\hline Violaxanthin & $5.2(6.5)$ & $31.4(6.6)$ \\
\hline Lutein & $10.3(3.9)$ & $17.9(3.9)$ \\
\hline Zeaxanthin & $5.5(1.8)$ & $14.1(1.8)$ \\
\hline
\end{tabular}




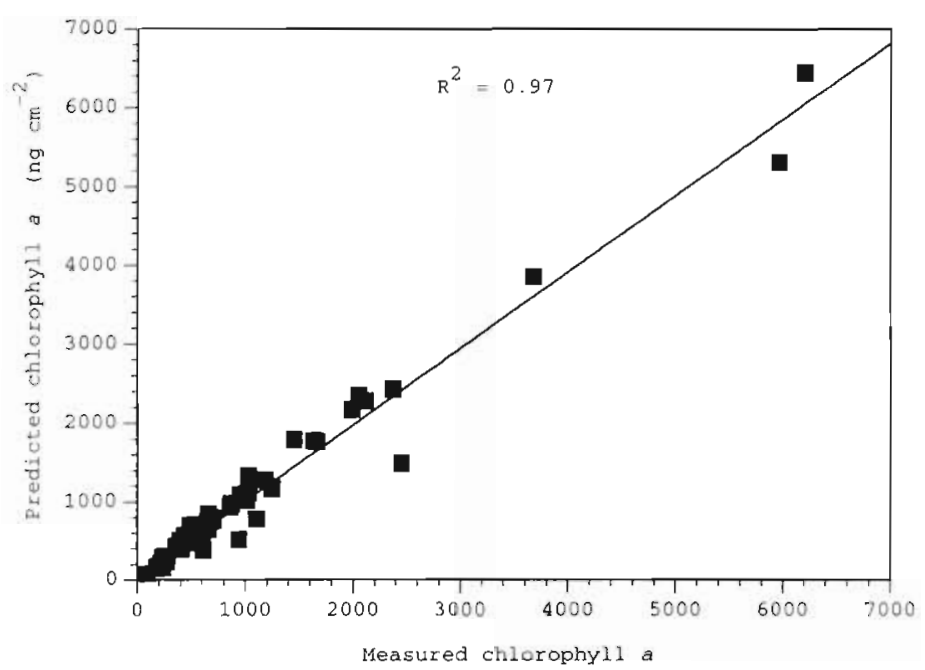

Fig. 9. Regression between measured values of chl a and values predicted by the model chl $a=-37.64+1.59$ Fuco +10.23 Viola +16.84 Zea; Fuco: fucoxanthin; Viola: violaxanthin; Zea: zeaxanthin

\section{DISCUSSION}

Enrichment with $\mathrm{N}$ and $\mathrm{P}$ had a general system effect on the primary production rates of the seagrass-epiphyte complex in Big Lagoon. Only the main effect of fertilizer was significant; all interaction terms containing this treatment were not significant (Table 2). Primary production rates were higher in enriched than in control plots for blades $(1.4 \times)$ and epiphytes $(2.0 \times)$. Coleman \& Burkholder (1994) found that ${ }^{14} \mathrm{C}$ uptake rates of epiphytes on Zostera marina $L$. were stimulated by nitrate addition in low-flow mesocosms; however, uptake rates by blades were not measured. In contrast, Coleman \& Burkholder (1995) were not able to demonstrate an increase in epiphytic primary production following nitrate enrichment of $Z$. marina beds in the field. They did, however, show that the abundance and species-specific production rates (using track light microautoradiography) of dominant epiphytic taxa were significantly affected by nitrate enrichment. Flow rates were high in Coleman \& Burkholder's (1995) field study but were low in their (1994) mesocosm experiment and in the present study. Perhaps this difference in flow rate explains the absence of stimulation of epiphytic production in Coleman \& Burkholder's 1995 study and its presence in their 1994 work and in this study. Under low-flow conditions, the autotrophic components may be nutrient-limited and act as a nutrient sink; under such conditions nutrient enrichment produces a system dominated by autotrophic processes (see mesocosm experiments of Nilsson et al. 1991).

As an alternative hypothesis, the increase in production of seagrass blades in enriched plots may have been caused by the transfer of fixed ${ }^{14} \mathrm{C}$ from the epi- phytic algae to the blades. There is little evidence in the literature, however, to suggest that a transfer of the magnitude measured in this study could occur.

Whereas primary production rates of both blades and epiphytes were stimulated by enrichment, only the biomass (as $\mathrm{g}$ dry $w t \mathrm{~m}^{-2}$ ) of epiphytes was increased by nutrient addition $(1.4 \times$ in enriched vs control plots). One explanation for the lack of response of blades to enrichment is that additional carbon uptake (indicated by ${ }^{14} \mathrm{C}$ uptake rates] was stored in underground roots and rhizomes rather than channeled to blades. Under oligotrophic conditions, Pérez et al. (1994) observed that seagrasses allocate a greater proportion of fixed carbon to root development to increase the capacity of roots to remove inorganic nutrients from the sediment pore water. At higher nutrient concentrations, shoot production increases; this is correlated with a reduction in the lifespan of shoots and hence a higher leaf turnover rate. The reason for this response is not known (Pérez et al. 1994). Thus, under oligotrophic or eutrophic conditions, an increase in aboveground biomass of blades may not be detected.

Other investigators have documented an increase in epiphytic biomass as a response to nutrient enrichment (Silberstein et al. 1986, Neverauskas 1987, Tomasko \& Lapointe 1991, Neckles et al. 1993, Williams \& Ruckelshaus 1993, Coleman \& Burkholder 1994, Lapointe et al. 1994). In the present study, HPLC was used to quantify epiphytic algal pigments (Table 6). The concentrations of chl a (all algal taxa), fucoxanthin (mainly diatoms), violaxanthin (brown algae), and zeaxanthin (mainly red algae) all exhibited significant increases. The dominance of diatoms in both control and enriched plots was reflected in the finding that $88 \%$ of the variation in chl a was explained by variation in fucoxanthin concentration. The dominance of diatoms in enriched conditions has also been reported by Coleman \& Burkholder (1994) for mesocosms containing Zostera marina and by Sundbäck \& Snoeijs (1991) for mesocosms containing shallow marine sandy sediments devoid of seagrasses.

The increase in epiphytic biomass and pigment concentrations in response to enrichment was paralleled by an increase in the abundance of macroalgae in enriched plots (Table 4). In particular, populations of the red alga Acrochaetium flexuosum and the brown alga Myriotrichia subcorymbosa increased greatly in enriched plots of all 3 seagrass hosts. A. flexuosum was the dominant non-diatom epiphyte on Halodule wrightii over an annual cycle in Mississippi Sound, USA and $M$. subcorymbosa was abundant at this site in winter (Moncreiff et al. 1992). These 2 taxa have 
remained the dominant non-diatom epiphytes in Mississippi Sound (M. J. Suilivan pers. obs.), which suggests that these seagrass beds are subject to nutrient enrichment. At the level of enrichment used in this study, it appears that the distribution and abundance, rather than the presence or absence, of macroalgal species are indicative of enrichment. Analysis of variance of pigment data showed that the abundance of the major groups of algae comprising the epiphytic community did not change significantly over time and did not differ significantly among seagrass species (there was no interaction between seagrass species and time). A higher level of enrichment may have resulted in even greater changes in the epiphytic algal community. Taxon diversity often decreases in response to enrichment, but in oligotrophic systems, nutrient enrichment may initially result in an increase in the diversity of taxa (Pringle 1990).

The green macroalga Enteromorpha often responds to water-column enrichment in the marine environment (Harlin \& Thorne-Miller 1981, Sundbäck \& Snoeijs 1991, Lapointe et al. 1994, Neckles et al. 1994). In this study, few green algae were observed as epiphytes (Table 3), but Enteromorpha did occur in high concentrations on nutrient tubes. Apparently, the rates of nutrient delivery in this study were below the threshold required to stimulate growth of Enteromorpha away from the source. In experiments designed to test the effects of current on fertilizer dispersion, Enteromorpha only colonized the tube containing fertilizer, whereas diatoms were the only algae to colonize the 2 tubes without fertilizer. Therefore, the presence of Enteromorpha was in response to the highest nutrient concentration rather than the result of nutrient tubes providing a better substrate for attachment than seagrasses. This suggests that an abundance of Enteromorpha in seagrass systems is indicative of high water-column nutrient concentrations, in particular, inorganic nitrogen (Harlin \& Thorne-Miller 1981).

The strongest response to nutrient enrichment in Big Lagoon occurred in beds of Halodule wrightii. Evidence to support this is as follows: (1) the highest diversity and abundance of non-diatom algae were found here (Table 4); (2) only in enriched plots of $H$. wrightii did epiphytes account for more than $50 \%$ of the combined blade + epiphyte biomass (Fig. 4b); and (3) the percent contribution of epiphytes to total (blade + epiphyte) production was equal for control and enriched plots of Syringodium filiforme and Thalassia testudinum but was 60 and $44 \%$, respectively, for enriched and control plots of $H$. wrightii (Fig. 4a). Even casual examination of the field sites on each sampling date revealed that blades of $H$. wrightii in enriched plots were densely covered by epiphytes. This covering was found to consist of filamentous red and brown algae and of chain-forming diatoms belonging to genera such as Grammatophora, Rhabdonema, Striatella, Hyalosira, and Licmophora. Such growths were less evident in enriched plots of $S$. filiforme and $T$. testudinum. A possible cause for the greater response of epiphytes of $H$. wrightii is that the blades of this seagrass received more light energy than the blades of the other 2 seagrasses. Perhaps the greater light intensity allowed epiphytes of $H$. wrightii to more efficiently utilize the added nutrients than the epiphytes of $S$. filliforme and $T$. testudinum. Unfortunately, we have no data on saturating light levels for control and enriched plots to support or refute this hypothesis. Morgan \& Kitting (1984) found that both blades and epiphytes of H. wrightii saturated at $1100 \mu \mathrm{E} \mathrm{m}^{-2} \mathrm{~s}^{-1}$ in Texas waters, where the mean percent contribution of epiphytes to total biomass was $50 \%$.

The opportunistic or 'pioneering' nature of Halodule wrightii in Florida Bay and the Florida Keys is well known (Powell et al. 1989, 1991, Tomasko \& Lapointe 1991, Lapointe et al. 1994). Under elevated nutrient concentrations $H$. wrightii may competitively displace Thalassia testudinum as the dominant seagrass species. Experimental studies have shown that nutrient enrichment is tolerated by $H$. wrightii but it significantly decreases blade turnover time and rhizome growth in $T$. testudinum (Tomasko \& Lapointe 1991, Lapoinie et al. 1994).

Accurate prediction of the effects of cultural eutrophication on seagrass systems requires the use of experiments which target the water column. Measurement of water-column nutrients, however, can be a poor indicator of the extent of eutrophication in aquatic systems because soluble nutrients are rapidly removed (Suttle \& Harrison 1988, Suttle et al. 1990, Tomasko \& Lapointe 1991). Because enrichment effects are thought to be mediated through the epiphytic algae, both epiphytes and their seagrass hosts should be used in monitoring water quality in these systems. Although algal biomass is a better indicator of trophic status than soluble nutrient concentrations (Valiela et al. 1990), measurements of biomass inherently include the dry weight of materials other than epiphytic algae. Primary production rates $\left({ }^{14} \mathrm{C}\right.$ uptake) provide an instantaneous measure of organic matter assimilation, whereas biomass measurements represent the long-term accrual of organic matter and do not reflect the rapid turnover rates of epiphytes (Borum 1987). Furthermore, in this study, there was no statistical correlation between primary production rates of epiphytes and their biomass $(r=0.22)$. As an alternative to dry-weight estimates of biomass our data demonstrate that chl a measurement is a valid indicator of the abundance of epiphytic algae. We strongly urge that future enrichment studies incorporate a methodology to measure carbon fixation rates and photosynthetic 
pigment concentrations to more accurately describe the response of the seagrass-epiphyte complex to nutrient enrichment and other environmental perturbations.

All 3 seagrass species and their epiphytes responded similarly to water-coluran enrichment. Fertilizer was significant as a main effect for all measured variables (production, biomass, and pigment concentrations). The strong response of epiphytes to enrichment suggests that cultural eutrophication could pose a serious threat to the seagrass beds of Big Lagoon as urbanization continues in the area surrounding Perdido Bay. Negative effects could be manifested as a reduction in the coverage of shallow-water sediments by seagrass beds and/or the elimination of one or 2 species, possibly converting Big Lagoon into a seagrass monoculture. Such a monoculture would probably be Halodule wrightii, as Powell et al. (1989, 1991) and Lapointe et al. (1994) have shown that $H$. wrightii will replace Thalassia testudinum under conditions of sustained nutrient enrichment.
Acknowledgements. Our utmost gratitude is extended to Dr Clarence Watson of Mississippi State University for his guidance, patience, and statistical expertise. We are indebted to Julian Veal, Deborah Keil, and Scott Phipps for their assistance with field and laboratory work. We also thank Julian Veal for editing the manuscript. Ginny Coleman's advice with regard to laboratory techniques was indispensable. We extend our appreciation to Director John Blankinship and Charles Blackston of the East Mississippi Community College Physical Plant Department for their assistance in the design and fabrication of equipment used in this project. A special thanks is accorded to Randall Ash for the use of his underwater camera. Dr Jon Pennock of the Dauphin Island Sea Lab provided advice on experimental design, particularly with regard to the dynamics of fertilizer release to the water column. This work is a result of research sponsored in part by the National Oceanic and Atmospheric Administration, U.S. Department of Commerce, under Grant no. NA16RG0155, the Mississippi-Alabama Sea Grant Consortium, and Mississippi State University. The U.S. Government and the Mississippi-Alabama Sea Grant Consortium are authorized to produce and distribute reprints notwithstanding any copyright notation that may appear herein. The views expressed herein are those of the authors and do not necessarily reflect the views of NOAA or any of its subagencies.

Appendix 1. Mean values for primary production $\left(n g \mathrm{C} \mathrm{cm}^{-2} \mathbf{h}^{-1}\right)$ of seagrass blades and epiphytes on each sampling date $(\mathrm{n}=2)$ Data are for mean comparison only. Statistical significance is not indicated. Halodule: Halodule wrightii; Syringodium: Syringodium filiforme; Thalassia: Thalassia testudinum; C:control; E: enriched

\begin{tabular}{|c|c|c|c|c|c|c|c|}
\hline & & October & January & April & June & August & September \\
\hline \multicolumn{8}{|c|}{ Seagrass production ( $\mathrm{ng} \mathrm{C} \mathrm{cm}^{-2} \mathrm{~h}^{-1}$ ) } \\
\hline Halodule & $\begin{array}{l}C \\
E\end{array}$ & $\begin{array}{r}589.3 \\
1169.0\end{array}$ & $\begin{array}{l}221.5 \\
402.3\end{array}$ & $\begin{array}{l}581.8 \\
657.8\end{array}$ & $\begin{array}{l}1273.3 \\
1231.8\end{array}$ & $\begin{array}{l}695.8 \\
934.3\end{array}$ & $\begin{array}{r}933.8 \\
1284.3\end{array}$ \\
\hline Syringodium & $\begin{array}{l}\mathrm{C} \\
\mathrm{E}\end{array}$ & $\begin{array}{l}656.0 \\
827.5\end{array}$ & $\begin{array}{l}217.3 \\
238.8\end{array}$ & $\begin{array}{l}768.5 \\
848.3\end{array}$ & $\begin{array}{l}583.0 \\
856.3\end{array}$ & $\begin{array}{l}490.5 \\
837.3\end{array}$ & $\begin{array}{r}530.0 \\
1137.0\end{array}$ \\
\hline Thalassia & $\stackrel{C}{E}$ & $\begin{array}{l}627.8 \\
743.8\end{array}$ & $\begin{array}{l}281.0 \\
374.3\end{array}$ & $\begin{array}{l}583.0 \\
502.3\end{array}$ & $\begin{array}{l}364.8 \\
517.5\end{array}$ & $\begin{array}{l}303.3 \\
460.5\end{array}$ & $\begin{array}{l}491.0 \\
738.5\end{array}$ \\
\hline \multicolumn{8}{|c|}{ Epiphyte production (ng C $\mathrm{cm}^{-2} \mathrm{~h}^{-1}$ ) } \\
\hline Halodule & $\begin{array}{l}\text { C } \\
E\end{array}$ & $\begin{array}{l}647.3 \\
907.0\end{array}$ & $\begin{array}{r}841.5 \\
1213.3\end{array}$ & $\begin{array}{r}130.3 \\
1946.0\end{array}$ & $\begin{array}{r}794.0 \\
2812.0\end{array}$ & $\begin{array}{l}467.5 \\
601.0\end{array}$ & $\begin{array}{r}448.5 \\
1021.5\end{array}$ \\
\hline Syringodium & $\begin{array}{l}\mathrm{C} \\
\mathrm{E}\end{array}$ & $\begin{array}{r}407.3 \\
1145.8\end{array}$ & $\begin{array}{r}752.8 \\
1216.3\end{array}$ & $\begin{array}{l}1150.5 \\
2995.0\end{array}$ & $\begin{array}{l}1326.5 \\
1037.0\end{array}$ & $\begin{array}{l}255.5 \\
690.3\end{array}$ & $\begin{array}{l}1386.3 \\
2155.5\end{array}$ \\
\hline Thalassia & $\begin{array}{l}\mathrm{C} \\
\mathrm{E}\end{array}$ & $\begin{array}{l}332.0 \\
410.0\end{array}$ & $\begin{array}{l}145.5 \\
303.6\end{array}$ & $\begin{array}{l}573.0 \\
745.0\end{array}$ & $\begin{array}{l}476.5 \\
859.0\end{array}$ & $\begin{array}{l}224.3 \\
133.8\end{array}$ & $\begin{array}{l}277.3 \\
715.8\end{array}$ \\
\hline
\end{tabular}

Appendix 2. Mean values for biomass $\left(\mathrm{g} d r y w \mathrm{t} \mathrm{m}^{-2}\right.$ ) of seagrass blades and epiphytes on each sampling date $(\mathrm{n}=2)$. Data are for mean comparison only. Statistical significance is not indicated. Halodule: Halodule wrightii, Syringodium: Syringodium filiforme; Thalassia: Thalassia testudinum; $\mathrm{C}$ : control ${ }_{i}$ E: enriched

\begin{tabular}{|c|c|c|c|c|c|c|}
\hline & & October & April & June & August & September \\
\hline \multicolumn{7}{|c|}{ Seagrass biomass (g dry wt $\mathrm{m}^{-2}$ ) } \\
\hline Halodule & $\begin{array}{l}\mathrm{C} \\
\mathrm{E}\end{array}$ & $\begin{array}{l}48.0 \\
71.1\end{array}$ & $\begin{array}{l}42.4 \\
33.7\end{array}$ & $\begin{array}{l}62.2 \\
98.3\end{array}$ & $\begin{array}{l}79.2 \\
50.2\end{array}$ & $\begin{array}{l}11.2 \\
39.9\end{array}$ \\
\hline Syringodium & $\begin{array}{l}\mathrm{C} \\
\mathrm{E}\end{array}$ & $\begin{array}{r}83.0 \\
149.8\end{array}$ & $\begin{array}{r}72.0 \\
100.8\end{array}$ & $\begin{array}{l}227.3 \\
104.2\end{array}$ & $\begin{array}{l}163.1 \\
165.5\end{array}$ & $\begin{array}{r}95.1 \\
111.1\end{array}$ \\
\hline Thalassia & $\begin{array}{l}\mathrm{C} \\
\mathrm{E}\end{array}$ & $\begin{array}{r}160.5 \\
96.4\end{array}$ & $\begin{array}{l}70.3 \\
69.0\end{array}$ & $\begin{array}{l}136.6 \\
138.4\end{array}$ & $\begin{array}{l}156.9 \\
155.1\end{array}$ & $\begin{array}{l}132.2 \\
120.1\end{array}$ \\
\hline \multicolumn{7}{|c|}{ Epiphyte biomass ( $g$ dry wt $\mathrm{m}^{-2}$ ) } \\
\hline Halodule & $\begin{array}{l}\mathrm{C} \\
\mathrm{E}\end{array}$ & $\begin{array}{r}67.8 \\
156.4\end{array}$ & $\begin{array}{l}77.4 \\
75.1\end{array}$ & $\begin{array}{l}11.6 \\
38.7\end{array}$ & $\begin{array}{l}29.3 \\
18.0\end{array}$ & $\begin{array}{r}6.6 \\
25.1\end{array}$ \\
\hline Syringodium & $\begin{array}{l}\mathrm{C} \\
\mathrm{E}\end{array}$ & $\begin{array}{l}66.0 \\
92.9\end{array}$ & $\begin{array}{r}49.0 \\
156.6\end{array}$ & $\begin{array}{r}136.7 \\
65.9\end{array}$ & $\begin{array}{l}57.9 \\
58.7\end{array}$ & $\begin{array}{l}68.5 \\
59.9\end{array}$ \\
\hline Thalassia & $\begin{array}{l}\mathrm{C} \\
\mathrm{E}\end{array}$ & $\begin{array}{l}38.8 \\
51.0\end{array}$ & $\begin{array}{l}43.3 \\
60.7\end{array}$ & $\begin{array}{l}107.5 \\
146.9\end{array}$ & $\begin{array}{l}45.2 \\
40.2\end{array}$ & $\begin{array}{r}64.2 \\
157.7\end{array}$ \\
\hline
\end{tabular}


Appendix 3. Mean values for HPLC analysis of epiphytic chl a and fucoxanthin (ng $\mathrm{cm}^{-2}$ ) for each seagrass species on each sampling date $(\mathrm{n}=2)$. Data are for mean comparison only. Statistical significance is not indicated. Halodule: Halodule wrightij;

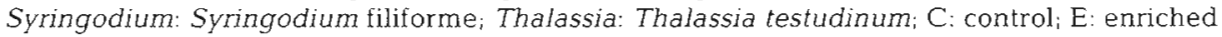

\begin{tabular}{|c|c|c|c|c|c|c|}
\hline & & January & April & June & August & September \\
\hline \multicolumn{7}{|c|}{ Chlorophyll a (ng cm$\left.{ }^{-2}\right)$} \\
\hline Halodule & $\begin{array}{l}\mathrm{C} \\
\mathrm{E}\end{array}$ & $\begin{array}{r}421.0 \\
3791.0\end{array}$ & $\begin{array}{r}342.0 \\
3531.0\end{array}$ & $\begin{array}{l}218.7 \\
577.8\end{array}$ & $\begin{array}{l}621.7 \\
591.8\end{array}$ & $\begin{array}{l}178.4 \\
520.8\end{array}$ \\
\hline Syringodium & $\begin{array}{l}\widetilde{C} \\
\mathrm{E}\end{array}$ & $\begin{array}{r}247.6 \\
1853.3\end{array}$ & $\begin{array}{r}525.3 \\
3059.1\end{array}$ & $\begin{array}{r}636.3 \\
1104.1\end{array}$ & $\begin{array}{r}808.8 \\
1734.3\end{array}$ & $\begin{array}{r}970.7 \\
2047.1\end{array}$ \\
\hline Thalassia & $\begin{array}{l}\mathrm{C} \\
\mathrm{E}\end{array}$ & $\begin{array}{l}151.4 \\
446.1\end{array}$ & $\begin{array}{l}420.5 \\
711.3\end{array}$ & $\begin{array}{l}595.5 \\
893.6\end{array}$ & $\begin{array}{l}550.3 \\
730.9\end{array}$ & $\begin{array}{r}407.0 \\
1069.0\end{array}$ \\
\hline \multicolumn{7}{|c|}{ Fucoxanthin ( $\mathrm{ng} \mathrm{cm}^{-2}$ ) } \\
\hline Halodule & $\begin{array}{l}C \\
E\end{array}$ & $\begin{array}{r}261.0 \\
1380.5\end{array}$ & $\begin{array}{r}154.9 \\
1122.6\end{array}$ & $\begin{array}{l}133.7 \\
227.0\end{array}$ & $\begin{array}{l}390.8 \\
211.3\end{array}$ & $\begin{array}{l}107.9 \\
299.6\end{array}$ \\
\hline Syringodium & $\begin{array}{l}\mathrm{C} \\
\mathrm{E}\end{array}$ & $\begin{array}{l}104.2 \\
914.6\end{array}$ & $\begin{array}{l}204.7 \\
918.2\end{array}$ & $\begin{array}{l}233.5 \\
528.3\end{array}$ & $\begin{array}{l}324.6 \\
715.0\end{array}$ & $\begin{array}{r}445.9 \\
1280.3\end{array}$ \\
\hline Thalassia & $\begin{array}{l}C \\
E\end{array}$ & $\begin{array}{r}58.8 \\
186.2\end{array}$ & $\begin{array}{l}173.3 \\
304.5\end{array}$ & $\begin{array}{l}334.2 \\
186.3\end{array}$ & $\begin{array}{l}255.5 \\
406.5\end{array}$ & $\begin{array}{l}277.0 \\
704.4\end{array}$ \\
\hline
\end{tabular}

\section{LITERATURE CITED}

Borum J (1987) Dynamics of epiphyton on eelgrass (Zostera marina L.) leaves: relative roles of algal growth, herbivory, and substratum turnover. Limnol Oceanogr 32: $986-992$

Burkholder JM, Wetzel RG (1990) Epiphyte alkaline phosphatase on natural and artificial plants in an oligotrophic lake: re-evaluation of the role of macrophytes as a phosphorus source for epiphytes. Limnol Oceanogr 35:736-747

Cambridge ML, McComb AJ (1984) The loss of seagrasses from Cockburn Sound, Western Australia. I. The time course and magnitude of seagrass decline in relation to industrial development. Aquat Bot 20:229-243

Coleman VL, Burkholder JM (1994) Community structure and productivity of epiphytic microalgae on eelgrass (Zostera marina L.) under water-column nitrate enrichment. J Exp Mar Biol Ecol 179:29-48

Coleman VL, Burkholder JM (1995) Response of microalgal epiphyte communities to nitrate enrichment in an eelgrass (Zostera marina) meadow. J Phycol 31:36-43

Duarte CM (1991) Seagrass depth limits. Aquat Bot 40: $363-370$

Harlin MM, Thorne-Miller B (1981) Nutrient enrichment of seagrass beds in a Rhode Island coastal lagoon. Mar Biol 65:221-229

Lapointe BE, Tomasko DA, Matzie WR (1994) Eutrophication and trophic state classification of seagrass communities in the Florida Keys. Bull Mar Sci 54:696-717

Legendre L, Demers S, Yentsch CM, Yentsch CS (1983) The ${ }^{14} \mathrm{C}$ method: patterns of dark $\mathrm{CO}_{2}$ fixation and DCMU correction to replace the dark bottle. Limnol Oceanogr 28: 996-1003

Millie DF, Paerl HW, Hurley JP (1993) Microalgal pigment assessments using high-performance liquid chromatography: a synopsis of organismal and ecological applications. Can J Fish Aquat Sci 50:2513-2527

Moncreiff CA, Sullivan MJ, Daehnick AE (1992) Primary production dynamics in seagrass beds of Mississippi Sound: the contributions of seagrass, epiphytic algae, sand microflora, and phytoplankton. Mar Ecol Prog Ser 87:161-171

Morgan MD. Kitting CL (1984) Production and utilization of the seagrass Halodule wrightii and its attached epiphytes. Limnol Oceanogr 29:1066-1.076
Neckles HA, Wetzel RT, Orth RJ (1993) Relative effects of nutrient enrichment and grazing on epiphyte-macrophyte (Zostera marina L.) dynamics. Oecologia 93:285-295

Neckles HA, Koepfler ET. Haas LW, Wetzel RL, Orth RJ (1994) Dynamics of epiphytic photoautotrophs and heterotrophs in Zostera marina (eelgrass) microcosms: responses to nutrient enrichment and grazing. Estuaries 17:597-605

Neverauskas VP (1987) Accumulation of periphyton biomass on artificial substrates deployed near a sewage sludge outfall in south Australia. Estuar Coast Shelf Sci 25:509-517

Nilsson P, Jönsson B, Swanberg IL, Sundbäck K (1991) Response of a marine shallow-water sediment system to an increased load of inorganic nutrients. Mar Ecol Prog Ser 71:275-290

Orth RJ, Moore KA (1983) Chesapeake Bay: an unprecedented decline in submerged aquatic vegetation. Science 222:51-53

Penhale P (1977) Macrophyte-epiphyte biomass and productivity in an eelgrass (Zostera marina L.) community. $J$ Exp Mar Biol Ecol 26:211-224

Pérez M, Duarte CM, Romero J, Sand-Jensen K, Alcoverro T (1994) Growth plasticity in Cymodocea nodosa stands: the importance of nutrient supply. Aquat Bot 47:249-264

Powell GVN, Kenworthy WJ, Fourqurean JW (1989) Experimental evidence for nutrient enrichment of seagrass growth in a tropical estuary with restricted circulation. Bull Mar Sci 44:324-340

Powell GVN, Fourqurean JW, Kenworthy WJ, Zieman JC (1991) Bird colonies cause seagrass enrichment in a subtropical estuary: observational and experimental evidence. Estuar Coast Shelf Sci 32:567-579

Pringle CMI (1990) Nutrient spatial heterogeneity: effects on community structure, physiognomy, and diversity of stream algae. Ecology 7:905-920

Rowan KS (1989) Photosynthetic pigments of algae. Cambridge University Press, New York

Sand-Jensen K, Borum J (1991) Interactions among phytoplankton, periphyton, and macrophytes in temperate freshwaters and estuaries. Aquat Bot 41:137-175

SAS Institute, Inc. (1988) SAS/STAT® User's guide, release 6.03. SAS Institute Inc, Cary, NC

Silberstein K, Chiffings AW, McComb AJ (1986) The loss of seagrass in Cockburn Sound, Western Australia. III. The effect of epiphytes on productivity of Posidonia australis Hook. f. Aquat Bot 24:355-371 
Strickland JDH, Parsons TR (1977) A practical handbook of seawater analysis. Bull Fish Res Bd Can 167:1-311

Sundbäck K, Snoeijs P (1991) Effects of nutrient enrichment on microalgal community composition in a coastal shallow-water sediment system: an experimental approach. Bot Mar 34:341-358

Suttle CA, Harrison PJ (1988) Ammonium and phosphate uptake kinetics of size-fractioned plankton from an oligotrophic freshwater lake. J Plankton Res 10:133-149

Suttle CA, Fuhrman JA, Capone DG (1990) Rapid ammonium cycling and concentration-dependent partitioning of ammonium and phosphate: implications for carbon transfer in plankton communities. Limnol Oceanogr 35:424-433

Editorial responsibility: Kenneth Heck Jr (Contributing Editor), Dauphin Island, Alabama, USA
Tomasko DA, Lapointe BE (1991) Productivity and biomass of Thalassia testudinum as related to water column nutrient availability and epiphyte levels: field observations and experimental studies. Mar Ecol Prog Ser 75:9-17

Valiela I, Costa J, Foreman K, Teal JM, Howes B, Aubrey D (1990) Transport of groundwater-borne nutrients from watersheds and their effects on coastal waters. Biogeochemistry 10:177-197

Walker DI, McComb AJ (1992) Seagrass degradation in Australian coastal waters. Mar Pollut Bull 25:191-195

Williams SL, Ruckelshaus MH (1993) Effects of nitrogen availability and herbivory on eelgrass (Zostera marina) and epiphytes. Ecology 74:904-918

Submitted: July 17, 1998; Accepted: October 28, 1998 Proofs received from author(s): March 16, 1999 